\title{
HIGHER EDUCATIONAL SYSTEM OF THE REPUBLIC OF SERBIA IN SUPPORT OF SUSTAINABLE DEVELOPMENT: CHALLENGES OF THE EU INTEGRATION
}

The paper examines the system of higher education in the Republic of Serbia in the context of educational paradigms and the development of the innovation and knowledge-based national economy. The subject of the research is higher education in Serbia in a life-long learning perspective as an essential component in achieving smart growth, capable enough to become a competent part of the European Higher Education Area. The aim of this paper is to examine the current situation in this area and the achievements of the new Strategy for Development of Education in Serbia by 2020 in the context of the expansion of higher education on the global level, as well as to emphasize the responsibility towards future generations for development of a more modern system of education based on the creativity of all participants in the learning process. In conclusion, the paper points out that the developmental orientation of educational system in the Republic of Serbia is building a new model of higher education.

Key words: higher education, sustainable development, interactive learning, evaluation methodologies, teaching/learning model, Serbia, EU

\section{Introduction}

The main challenge, which education system in Serbia faces, is how to build a contemporary model of education that will facilitate the development of the individual in the working environment and other life situations. Substantial differences in the level of regional development in Serbia, high unemployment rates and depopulation trends, suggest that the development of Serbia must be based on supporting and advancing creative and production qualities of human resources in a lifelong learning context.

Professor Milica Vujičić, PhD, State University of Novi Pazar - Department of Economic Sciences, Novi Pazar, e-mail: vujicicmilica@yahoo.com

** Assistant Professor Lela Ristić, PhD, Faculty of Economics, University of Kragujevac, e-mail: 1ristic@kg.ac.rs 
Educational system of Serbia went through at least twenty educational reforms, however, as a rule, these reforms were partial, without an appropriate insight into the existing issues and implications. In modern environment, there is a pronounced opposition of short term economical goals on one hand and the development mission of education on the other, resulting in the adoption of a new Strategy for Development of Education in Serbia by 2020.

The key hypothesis this paper is built upon, is that educational attainment and literacy have a crucial role to play in meeting the many socio-economic, demographic, environmental and technological challenges that the Republic of Serbia and its citizens face today and will be facing in the years to come. Furthermore, the special hypothesis states that the previous reforms of the education system at all levels, especially the higher education, did not contribute to generating innovation in support of sustainable development, as well as the transfer of knowledge aimed at overcoming the critical problems and meeting future challenges.

To test the initial hypothesis, the paper applied qualitative methodology based on the study and descriptive analysis of the defined problems. Analysis of the relevant literature, publications of international organizations and official statistical sources, enabled the comparison and synthesis of different views, identification of the situation and status of higher education and pointed to the necessity of building a modern model of higher education in the Republic of Serbia.

Based on the formulated research subject, objectives and hypothesis, this paper will in its first section, look into knowledge increment and expansion of the internationalization of the system of higher education on a global scale, while the second section will deal with the development of higher education in the Republic of Serbia and issues related to the opening of negotiations on Chapter 26, particularly access to education and the acquis communautaire. The concluding remarks, in addition to a critical analysis, underline the importance of the implementation of the ambitious goals of the Strategy of Higher System Development in Serbia by 2020, in the function of improving regional and international reputation and competitive position of the higher education in the Republic of Serbia.

\section{Knowledge increment and internationalization of tertiary education}

The ongoing trend in contemporary society is the expansion of general education and new knowledge. Such trend requires that learning and development become lifelong processes. The need to respond to the expansion of new challenges initiates upgrading of all systems of education, including formal educational institutions, as well as interconnecting of the components of formal and non-formal education. 
Formal learning includes the hierarchically structured school system that runs form primary school through the university and organized school-like programs created in business for technical and professional training (Conner, 2009). Non-formal education offers a variety of educational programmes that can be classified into two general categories: professional programmes (acquiring different skills and knowledge) and educational programmes (learning attitudes and positive life values). In the last forty years, there has been an expansion and popularization of higher education across the globe. The universities of different profiles and diversified curricula were established, while the features such as efficiency, quality and responsibility gained in importance.

Growth in enrollment in higher education institutions is recorded on all continents, and the causes of such growth are numerous: increased demand for services offered by the higher education sector; social mobility; increased participation of women; rapid technological development that expanded opportunities for access to knowledge and contributed to the development of the new models of education. Furthermore, in order to meet the growing demand for services provided by the higher education sector, numerous private institutions of higher education were established in many countries in recent decades.

The internationalization of higher education has been a major feature in the global system of higher education in recent decades. Although the mobility of students and teachers is one of the phenomena that is the most important and most researched in the last few decades (Tremblay, 2001, pp. 39-67), there is also a wide range of different educational programmes and activities that contribute to the internationalization of education, internationalization of institutions and their programmess, as well as the international integration of the institutions of higher education, such as the Bologna Process - the establishment of the EHEA (European Higher Education Area).

In some OECD countries that are facing declining enrollment rates concerning universities, the problem of sustainability of institutions of higher education was solved by internationalization and attracting students from other world countries and regions. On the other hand, in transitional countries, the opportunities for their students to study abroad made it possible to relieve pressure related to the growth in demand for higher education and requests to expand capacities of the existing national universities (Van Der Wende, 2001, p. 250).

Numerous universities in the world have achieved great success in the implementation of new communication and socially oriented technologies. The emergence and development of the massive open online courses (MOOC), made it possible for students from every part of the globe to access high quality curricula and lectures given by eminent professors, as well as facilitated communication between the MOOC participants. The development of Internet-based education programmes/e-learning, targets the specific career- and skill- based needs. Although this form of education has a great importance for the social 
development and economic prosperity, it is not well adapted to the traditional organization of higher education and quality control mechanisms, thus it creates new challenges that the universities around the world have to face (OECD, 2007, p. 88). One of the problems created by the implementation of these technologies is related to the loss of credibility of many tertiary institutions in the world that offer on-line courses, which brings into question the value of degrees that are issued by these institutions.

Competitiveness and market mechanisms gained in importance in the field of higher education as a result of increased offer, privatization, cost and internationalization of higher education. The emergence of global rankings of universities, as well as increasing impact and importance of these institutions, drives the higher education institutions to strengthen their reputation and give attention to market positioning, in order to attract eminent professors and top students or investors (Van Vught \& Ziegele, 2012). The emergence of the first global ranking of universities in 2003, i.e. the Academic Ranking of World Universities - ARWU, also known as the Shanghai Ranking, as well as other ranking lists, enabled universities to rely on the external and transparent instruments to prove their quality and build reputation (Usher and Savino, 2006, p. 6). The world's elite universities are not so much concerned with the ranking lists due to their long-standing reputation (e.g. Harvard University, Stanford University, University of California, Berkeley, University of Cambridge), on the other hand, new universities in developing countries, which are struggling to build their image and ensure as much favorable market position as possible, are very aware of the importance of such rankings, especially the Shanghai Ranking. Although Shanghai Ranking is one of the most reliable ranking lists, it is also criticized for being biased towards science-focused institutions and favoring them over the social sciences and humanities (Zirulnick, 2010).

\section{The development of higher education system in the Republic of Serbia}

Tertiary education is exceptionally important for the Republic of Serbia and is a part of the EHEA. The system of higher education, in line with the mentioned new Strategy, will be harmonized and consolidated through (SROS, 2012, p. 87): (a) finalization of structural reforms; (b) improvement of the quality assurance system referring to the education process which includes research, lifelong learning and promotion of employment opportunities; (c) better availability of study programmes; (d) mobility.

Serbian system of higher education includes two types of studies, academic studies (implemented through three cycles, i.e., basic/bachelor/undergraduate studies, Master studies and PhD studies) and vocational studies which are realized as two-cycle study programmes (Figure 1). 
Figure 1: Schematic review of higher education system in Serbia

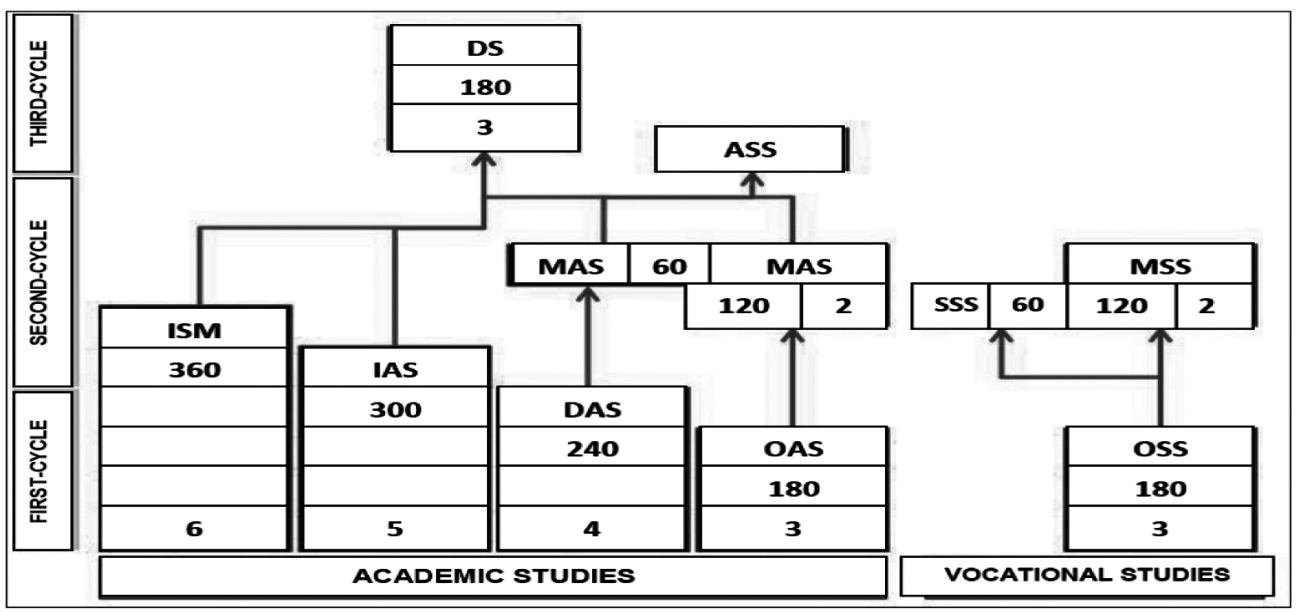

* ISM - Integrated studies of medicine (360 ECTS); IAS - Integrated academic studies (300 ECTS);

DAS - Graduate academic studies (240 ECTS); OAS - Bachelor basic academic studies (180 ECTS); OSS - Bachelor (appl.) Basic vocational studies (180 ECTS); MAS - Master academic studies (60 or 120 ECTS); MSS - Master of vocational studies (120 ECTS); SSS - Specialist vocational studies (60 ECTS); ASS - Specialist academic studies (60 ECTS); DS - PhD studies (180 ECTS).

Source: SROS, 2012, p. 85.

Pursuant to the Strategy for the Development of Education in Serbia by 2020, higher education institutions shall organize and implement lifelong learning, in accordance with the general technological progress, the relevant developments and the needs of the labor market, while the lifelong learning shall be in compliance with the ECTS system, and shall include elements related to non-formal education (SROS, 2012, p. 88).

The two main indicators concerning the educational structure of the population - educational attainment and literacy- best describe the general level of educational structure of the population, as well as the achieved level of socioeconomic development of the country. Table 1 and Graph 1 give a comparative overview of data on the population aged 15 and over by educational attainment, according to the data provided by the Censuses implemented from 1991 to 2011. 
Table 1: The population aged 15 and over by educational attainment, by censuses from 1991 to 2011

\begin{tabular}{|l|c|c|c|c|c|c|}
\hline & $\mathbf{1 9 9 1}$ & $\mathbf{\%}$ & $\mathbf{2 0 0 2}$ & $\mathbf{\%}$ & $\mathbf{2 0 1 1}$ & $\%$ \\
\hline Republic of Serbia & 6294350 & 100 & 6321231 & 100 & 6161584 & 100 \\
\hline Without educational attainment & 590682 & 9.38 & 357552 & 5.66 & 164884 & 2.68 \\
\hline Incomplete primary education & 1522639 & 24.19 & 1022974 & 16.18 & 677499 & 11.00 \\
\hline Primary education & 1541778 & 24.49 & 1509462 & 23.88 & 1279116 & 20.75 \\
\hline Secondary education & 2022048 & 32.13 & 2596348 & 41.07 & 3015092 & 48.93 \\
\hline High education & 241416 & 3.84 & 285056 & 4.51 & 348335 & 5.65 \\
\hline Higher education & 322888 & 5.13 & 411944 & 6.52 & 652234 & 10.59 \\
\hline Unknown & 52899 & 0.84 & 137895 & 2.18 & 24424 & 0.40 \\
\hline
\end{tabular}

Source: SORS, 2013, p. 18.

Development of the higher education system in the Republic of Serbia kept up with the country's economic development. In 2012, a total of 231,661 students (out of which $55.8 \%$ were women) were enrolled in Serbia, out of which $84 \%$ of the students were enrolled in state faculties and colleges.

Graph 1: The population aged 15 and over by educational attainment, by censuses from 1991 to 2011

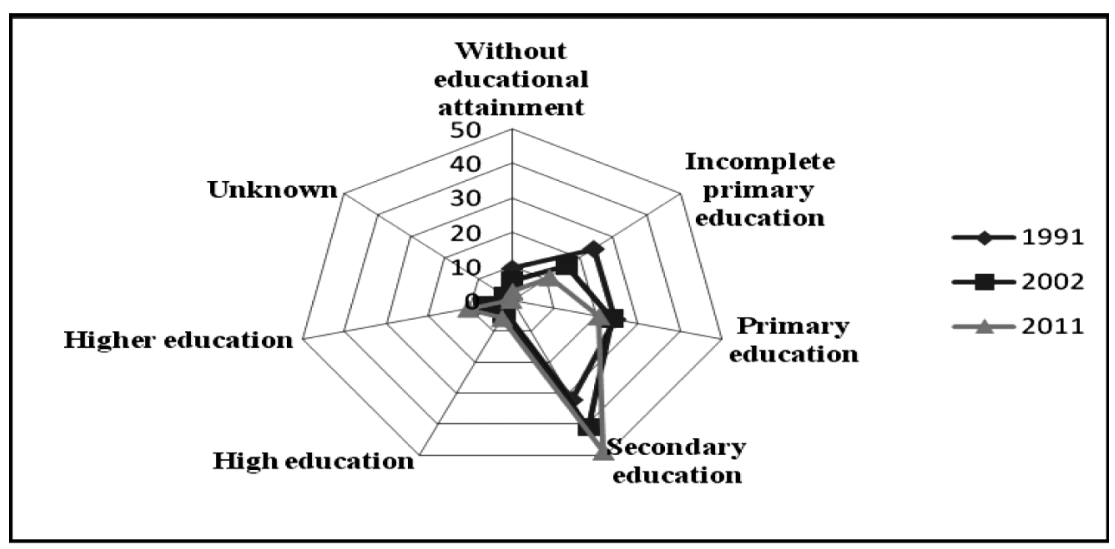

Source: Authors, on the basis of SORS, 2013, p.18.

The implementation of the accreditation process had certain positive effect on the level of organization of academic studies, however, the process of ensuring the quality of teaching is often not integrated with the process of teaching and is not established in line with the requirements. Average length of studying 
prior to implementation of the Bologna principle was 7-8 years, while after the implementation of the Bologna principles it has been reduced to about 5 years.

Concerning the last three years, the number of students enrolled in the basic academic studies (BAS) is about 37,000 and they attend 188 higher education institutions, also it is estimated that about $42 \%$ of inhabitants older than 19 years of age are enrolled in the BAS (Graph 2).

Graph 2: Number of new students enrolled in BAS

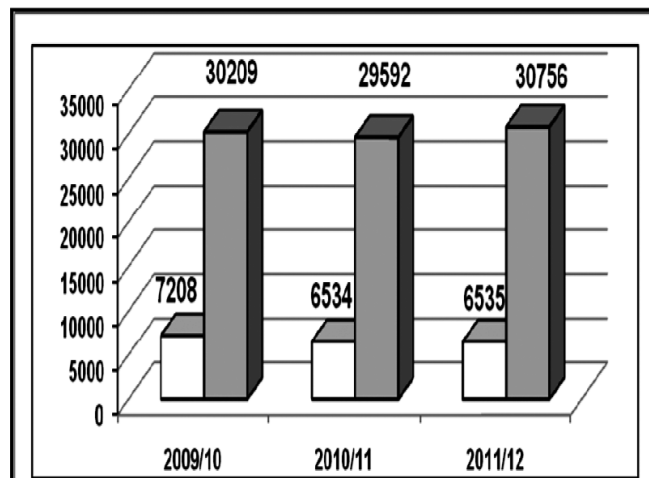

DPrivatehigher education institutions पStatehigher education institutions



Source: SORS, 2012; SROS, 2012, p. 99.

Total number of students enrolled in the BAS is 42,445 (Graph 3), which is quite satisfactory, considering that this number of students exceeds the current needs for about 14\%.20,299 students are enrolled in the accredited Master degree programmes while 3,263 students are enrolled in third-cycle programmes - PhD programmes.

Graph 3: Accredited bachelor/basic, master and PhD studies total number of new students to be enrolled in the first year of all accredited academic studies (total 66007)

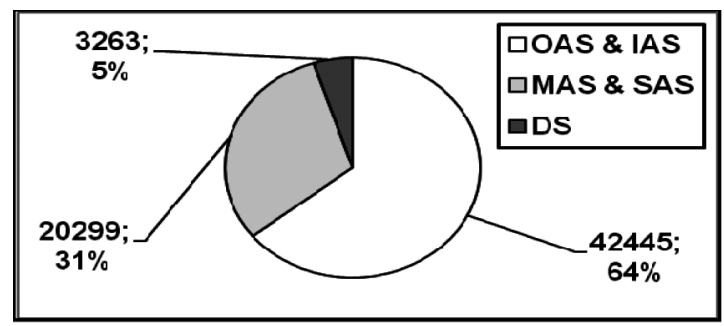

Source: CAQA, 2012; SROS, 2012, p. 100. 
At least $10 \%$ of students who complete their Master's degree programmes get into $\mathrm{PhD}$ programmes. About $60 \%$ of $\mathrm{PhD}$ students complete their studies in the prescribed period of time, while the quality of programmes is determined by the standards applied in the EHEA countries. At least $10 \%$ of the PhD study programmes are joint degrees and programmes with foreign universities. Number of persons completing $\mathrm{PhD}$ studies ranges between 65 and 75 per year per one million people, which is much lower than the average in the ERA (European Research Area).

\section{Competitiveness in the field of higher education in the Republic of Serbia}

Based on the Report of the Commission for Accreditation and Quality assurance (CAQA), Serbia has accredited 18 state and private universities, as well as a number of non-accredited higher education institutions (CAQA, 2014, pp. 3-4). In such an environment there is a sort of market competition over which institution would enroll the highest number of students and all interested parties take part in it: state and private accredited and non-accredited universities, faculties and colleges. As the race follows market principles, these institutions use certain signals and marketing tools in order to prove their quality, build reputation and design the best possible self-promotion, mostly for purposes of commercialization.

A large number of faculties and universities are faced with new challenges, and one of the most significant challenges is the issue of the quality teaching staff, student and teacher mobility, and greater use of active learning which facilitates practical application of acquired knowledge. There is a competition between the universities in the Republic of Serbia, which all strive towards receiving better rankings, however, only the University of Belgrade succeeded in this effort and was included in Shanghai Ranking among the top 500 universities in the world in April 2012. In 2013 and 2014, this university improved its ranking in the group between 301 and 400 universities in the world. The University achieved the best rankings in the field of science - mathematics and was placed in a group between 101 and 200 top mathematics faculties/departments in the world (University of Belgrade, 2014).

The Strategy for Development of Education in Serbia by 2020, predicts that the number of enrolled students in Serbia, as a part of the European Higher Education Area, would increase, because it is estimated that less than $23 \%$ of people aged 30 to 34 have a university degree. According to the field of education, most students opt for the social sciences, business studies and law, i.e. $36.8 \%$ (Table 2). 
Higher educational system of the Republic of Serbia in support of sustainable...147

Table 2: Students enrolled in tertiary education and fields of education

\begin{tabular}{|l|c|c|c|}
\hline Field of education & $\begin{array}{c}\text { Students enrolled in } \\
\text { tertiary education } \\
\mathbf{2 0 1 1 / 1 2}\end{array}$ & $\begin{array}{c}\text { \% Students } \\
\text { enrolled in tertiary } \\
\text { education 2011/12 }\end{array}$ & $\begin{array}{c}\text { Graduated students } \\
\text { by fields of } \\
\text { education, 2011 }\end{array}$ \\
\hline All & 231661 & 100 & 47523 \\
\hline Education & 16088 & 6.9 & 4652 \\
\hline Arts & 25106 & 10.8 & 5169 \\
\hline Social sciences, business and law & 85265 & 36.8 & 16680 \\
\hline $\begin{array}{l}\text { Natural sciences, mathematics } \\
\text { and computing }\end{array}$ & 23788 & 10.3 & 4059 \\
\hline $\begin{array}{l}\text { Engineering, manufacturing } \\
\text { and construction }\end{array}$ & 34873 & 15.1 & 7725 \\
\hline Agriculture and veterinary & 7555 & 3.3 & 1121 \\
\hline Health and welfare & 20249 & 8.7 & 4055 \\
\hline Services & 18737 & 8.1 & 4062 \\
\hline
\end{tabular}

Source: SORS, 2013a, pp. 99-103.

Goals of the Strategy of Higher System Development in Serbia by 2020 target the following key priorities (SROS, 2012, p. 105): 1) quality improvement; 2) harmonization of curricula with the market needs; 3 ) increased efficiency of studies; 4) increased scope and availability of academic studies; 5) internationalization of academic studies; 6) increased student mobility; 7) modernization of the organization of the academic studies. In this sense, the SWOT analysis of the tertiary education in the Republic of Serbia is very important (Table 3). 
Table 3: SWOT analysis of the tertiary education in the Republic of Serbia

\begin{tabular}{|c|c|}
\hline STRENGTHS & WEAKNESSES \\
\hline $\begin{array}{l}\text { - tradition and experience in tertiary education } \\
\text { - developed network of tertiary education } \\
\text { institutions } \\
\text { - quality of certain faculties and significant number } \\
\text { of professors } \\
\text { - developed curricula in number of educational } \\
\text { areas } \\
\text { - accessibility of tertiary education }\end{array}$ & $\begin{array}{l}\text { - reluctance of professors to accept change } \\
\text { - insufficient involvement in extracurricular } \\
\text { activities } \\
\text { - inconsistency of quality standards } \\
\text { - inadequate level of quality } \\
\text { - insufficient harmonization with the labor } \\
\text { market } \\
\text { - inadequate National Qualifications Framework } \\
\text { - unacceptance of foreign degrees/diplomas } \\
\end{array}$ \\
\hline & - insufficient mobility of students and professors \\
\hline OPPORTUNITIES & \begin{tabular}{|c|} 
THREATS \\
\end{tabular} \\
\hline $\begin{array}{l}\text { - high interest of young people in tertiary education } \\
\text { - increased interest of students from the former } \\
\text { Yugoslav Republics, Africa and the Middle East } \\
\text { - accession of Serbia to the EHEA } \\
\text { - internationalization of curricula } \\
\text { - compliance of the outcomes of study programmes } \\
\text { with market demands } \\
\text { - increasing the quality of the study programmes } \\
\text { - strategic partnerships between the public and } \\
\text { private sector }\end{array}$ & $\begin{array}{l}\text { - favorable conditions to study in some EU } \\
\text { countries } \\
\text { - permanent migration of young people abroad } \\
\text { - decline of standards and underemployment of } \\
\text { graduates } \\
\text { - opening of foreign tertiary institutions without } \\
\text { applying quality assessment } \\
\text { - dropping out of tertiary education } \\
\text { - corruption }\end{array}$ \\
\hline
\end{tabular}

Source: Authors, on the basis of SROS, 2012, pp. 103-104.

The current system of higher education is not sufficiently harmonized with the labor market needs and competencies that are necessary for the success. Graduated students, who are just starting their working life, usually lack in competencies which are related to real life situations. Fine tuning of the educational system with the social and economic needs will result in faster integration into real life situations and labor market after graduation. Therefore, the mentioned new strategy provides for the special institution which will monitor labor market needs in a professional and qualified manner, as well as produce estimates on future needs of the Republic of Serbia for qualified employees and publish periodic reports of its findings in order to provide guidance to higher education institutions in terms of focusing their educational services, i.e. studying programmes and capacities (SROS, 2012, p. 112). 


\section{Internationalization and cooperation}

Official opening of negotiations with the EU on chapter 26, which refers to education and culture, highlights the importance of the implementation of the Strategy for the Development of Education by 2020 and it s Action Plans, which sets out the necessary changes in the field of tertiary education.

Horizontal and vertical student mobility in terms of academic studies is implemented in the tertiary education system in Serbia. However, the organized departure of university students from Serbian universities to the EHEA countries in order to complete certain study programmers is very rare. On the other hand, there is a growing trend of studying abroad, primarily in the EHEA countries, however, this is not the part of the inter-university cooperation, but the result of independent decisions of students to complete their studies abroad, especially in countries where the cost of academic studies is affordable and acceptable to those who can cover the costs of living abroad during their studies by themselves or by means of scholarships. Since Serbian universities implement the Bologna Process, it allows them to work more closely with the universities in the EHEA countries. However, despite the numerous bilateral agreements related to higher education with countries from different regions, the establishment of the joint programmers and joint degrees with foreign universities is very rare. Recognition of foreign qualifications is very difficult in some higher education institutions, as they apply their specific criteria and standards (for recognition of $\mathrm{PhD}$ degrees, for example), or perform equalization of degree programmers (which is not in compliance with the legal procedure of recognition of foreign degrees), requiring students with valid degrees awarded by foreign universities to take additional exams. There are only few programmers that are offered in English or another foreign language, therefore there are not many foreign students, except those from the former Yugoslav Republics, who can attend courses in Serbian language (SROS, 2012, p. 101). In contrast to the mobility of students, the data related to the mobility of professors/academic staff members are scarce. The mobility of professors is mainly related to short-term leaves, exchange visits, as well as cooperation on scientific research projects.

Serbia must also draft the Law on National Qualifications Framework, produce the classification of occupations, as well as the list of qualifications needed for certain occupations and to adopt the Regulation on prohibiting the discrimination of the children of migrant workers. Namely the Directive 486/EEC on the Education of the Children of Migrant Workers was passed in EU in 1977. The Directive prescribes that the children of migrant workers, who are nationals of other EU member countries, have equal rights in education as the native students concerning all levels of education. This Directive is partially transposed in laws and regulations governing the primary and secondary education, however discrimination is still present in higher education. Foreign students are not entitled 
to free tuition and must pay scholarship. Therefore, it is necessary to comply the rules and regulations with those in the EU concerning the people who come to study and/or work in the Republic of Serbia (simplified visa requirements, issuance of permits, health insurance and other requirements in the field of labor relations), as well as legislation concerning teaching at the universities.

As the EU candidate country, Serbia will participate in the Erasmus plus programmed both in its centralized and decentralized activities. This means that students from Serbia have opportunity to attend the prestigious European universities, to be entitled to free tuition and to be awarded scholarships. In this regard, an agreement should be signed by the end of April 2014, and the membership fee in the amount of $€ 185,000$ should be paid, which has already been included in budget planning (Masic, 2014, p. 7).

\section{The necessity for implementing a new model of higher education}

Development of a new model of higher education in Serbia, along with the modernization of the curricula, requires the significant shift in teaching methods, learning methods and styles and instruction. Prevailing traditional education, which is practiced in most educational institutions, is largely based on the model of rote learning which rests on the postulate that knowledge is a goal in itself. The goal of this learning process is the transfer of knowledge from the teacher to the student who is a passive recipient of knowledge. Didactic and methodical approach typical of such concept of education considers the students' needs and competencies, however, the teaching itself is not focused on cognitive processes since there is no feedback. Typically, after the class has ended, the teacher has no feedback on the extent of the new knowledge acquired by students. Therefore, it is impossible to take affirmative or corrective measures and, as a rule, appropriate instructional strategies are implemented with a considerable delay. As the knowledge economy is based on "the production and distribution of knowledge and information, rather than the production and distribution of things" (Sawyer, 2006, pp. 41-48), it is necessary to make a qualitative shift in the contemporary educational model from teacher-directed rote learning model (i.e. teaching model) based on lecturing or the simple transfer of knowledge from the teacher to the students, to the student-centered learning model which is focused on active participation of both students and teachers in the learning process, including the elimination of useless knowledge. Student-centered learning process not only enables students to actively participate in instruction and learning, but also allows them to choose the material and the content of learning. In doing so, a student is able to transform collected information into knowledge at his/her own pace, to manage and analyze the information and data and transform them into applicable knowledge. Also, the current educational 
model is focused on the content being taught, so it is necessary to direct a new educational model towards the way that something is taught (Mrvac et al, 2010). This means that the student should be encouraged to get the necessary data, to transform it and use it in a way that would allow others to also learn from such data. The new model encourages creativity of students, using the independent as well as team work, by developing various projects and presentations based on the research, discussions in classes, information provided by academic networks, and etc. This all contributes to improving and advancing knowledge and skills in the process of lifelong learning. With a new approach to educational pedagogy, where theory and practice are effectively linked (Korthagen et al., 2006), the role of the teacher in the learning model is to transfer his/her knowledge and experience to students and, at the same time to instruct them.

The evaluation method of acquired competencies is one of the key issues of the educational system (Birenbaum et al., 2006, pp. 61-67). In the current educational system the knowledge acquired by the students is assessed at the end of the semester by the teachers. In the course of the educational process, students focus on the passing their exams and their main objective is to obtain a degree/ diploma. Student assessment is much more objective if it is based on several parameters, and if the evaluation is done not only by teachers but also by the students' peers, self-assessment and taking into account the overall engagement of the student during the semester. In this way, the quality and level of communication between students and teachers is increased and results in better knowledge, not just getting a degree/diploma.

Development and implementation of learning model could significantly contribute to a faster and better development of the students' competencies and skills, which would result in efficient development of the education system and the society as a whole.

\section{Concluding remarks}

In addition to the positive changes in many areas of higher education, there are also many limitations. The time length of study programmes is not adapted to the capabilities of students with a full time job, because they have difficulties to achieve the 60 ECTS per year. Distance learning (on-line) that best suit them, is limited due to the decision of the National Council for Higher Education which prescribed that maximum $30 \%$ of the total numbers of students are entitled to distance learning. The more comprehensive use of active learning is required, as well as learning that could be applied in practical and real life situations. The research and research papers conducted by students are insufficiently applied in the classroom. The classical way of instruction/teaching dominates, where the student is largely passive subject who is expected to understand and 
learn what he was thought, and to prove such knowledge on exams. Although the implementation of the Bologna Process has contributed to better interaction between students and professors during the semester, it is sometimes reduced to formalities (lectures and exercises). Corruption was present at some faculties and colleges. There are also irregularities in the performance of requirements by students (e.g., plagiarism in the form of copying term and research papers written by other people and the like). A large number of examination periods during the school year disrupt the educational process. The largest number of university professors have not passed courses concerning teaching methods, didactics, pedagogy and the like, which negatively affects the educational work of individual teachers and the results of that work. Also, it is necessary to harmonize the curricula of academic studies with the needs of the economy, as well as establish cooperation with the business sector in terms of the realization of practical training of students, so that students can acquire more knowledge, skills and competencies that are relevant to employers' needs during their studies. The greater financial support from public funds for the research projects of the $\mathrm{PhD}$ students is required, as well as the development and networking of teachers and researchers in higher education institutions, in order to create a joint laboratories and thus receive the status of centers of excellence that attract domestic and foreign companies and realize various forms of cooperation. Higher education institutions should make additional efforts to engage the employed persons in formal and informal education, which would help them, meet the challenges of the new business milieu. The key hypothesis this research rests upon is confirmed and refers to the observation that the Republic of Serbia does not have an adequate system of higher education and those traditional learning models with strictly defined teacher and student roles prevail at Serbian universities. Therefore, substantial changes in the higher educational system are necessary in order to build a modern model of higher education, which must consider the individual capabilities of students to acquire knowledge, create, innovate and apply the acquired knowledge, which is very important for joining the EHEA and the EU accession. 


\section{References}

- Birenbaum, M., Breuer, K., Cascallar, E, Dochy, F., Dori, Y., Ridgway, J. \& Wiesemes, R. (2006): „A Learning Integrated Assessment System“, in: R. Wiesemes, G. Nickmans A. (Eds.), Educational Research Review, 1(1), 61-67.

- CAQA (2012): Commission for Accreditation and Quality Assurance, Belgrade: Republic of Serbia /online/, Retrieved on $27^{\text {th }}$ December 2012 from http://www.kapk.org/

- CAQA (2014): Yearly report of the CAQA activity in the period from 7 April 2012 - 7 April 2013. Belgrade, Republic of Serbia: Commission for Accreditation and Quality Assurance.

- Conner, M. (2009): Introducing Informal Learning /online/, Retrieved on $30^{\text {th }}$ September 2010 from http://marciaconner.com/intros/informal.html

- Eurostat - Database (2011): Eurostat /online/. Retrieved on 28th December 2011 from http://epp.eurostat.ec.europa.eu/

- Korthagen, F., Loughran, J. \& Russel, T. (2006): „Developing fundamental principles for teacher education programs and practices", Teaching and Teacher Education, 22(8), 1020 - 1041.

- Masic, Z. (2014): „Srbija ocekuje pozitivan izvestaj EK o obrazovanju“ [Serbia expects positive EC report on education]. Politika [Politics], 10 April 2014, 7, Belgrade

- Mrvac, N., Tomisa, M. \& Milkovic, M. (2010): „Developing a modern model of higher education", Technics Technologies Education Management, 5(4), 700-709.

- OECD (2007): Giving Knowledge for Free: the Emergence of Open Educational Resources, OECD Paris.

- OECD (2012): Education at a Glance 2012: OECD indicators, OECD Paris.

- OECD (2012a): „How is the Global Talent Pool Changing?“, Education Indicators in Focus, 2012/5, OECD Paris.

- Sawyer, R. K. (2006): „Educating for innovation“, Thinking Skills and Creativity, 1, 41-48.

- SORS (2012): Statistical Office of the Republic of Serbia, Belgrade: Republic of Serbia /online/. Retrieved on 27th December 2012 from http:// webrzs.stat.gov.rs/WebSite/

- SORS (2013): 2011 Census of Population, Households and Dwellings in the Republic of Serbia, Population, Educational Attainment, Literacy and Computer Literacy, Data by municipalities and cities, Statistical Office of the Republic of Serbia, supported by the EU, Belgrade

- SORS (2013a): SGS 2013 [Statistical Yearbook of the Republic of Serbia 2013]. Belgrade: RZS [SORS - Statistical Office of the Republic of Serbia]. 
- SROS (2012): Strategija razvoja obrazovanja u Srbiji do 2020. godine [Strategy for Development of Education in Serbia by 2020], Government of the Republic of Serbia, Belgrade

- Tremblay, K. (2001): „Student Mobility between and towards, OECD Countries: A Comparative Analysis", In: International Mobility of the Highly Skilled, OECD Publishing, Paris, France

- UNESCO Institute for Statistics Data Centre (2009): Data Centre /online/. Retrieved on 30th September 2009 from http://stats.uis.unesco.org/

- University of Belgrade (2014): University of Belgrade Amongst 400 Top Ranked in the World /online/. Republic of Serbia: University of Belgrade. Retrieved on 27th April 2014 from http://www.bg.ac.rs/en/vest.php?id=155

- Usher, A. Savino, M. (2006): A World of Difference: A Global Survey of University League Tables. Canadian Education Report Series, Washington, DC, Toronto, ON, and Melbourne: EPI - Education Policy Institute, Australia

- Van Der Wende, M.C. (2001): „Internationalization Policies: About New Trends and Contrasting Paradigms". Higher Education Policy, 14, 249259. doi:10.1016/S0952-8733(01)00018-6.

- Van Vught, F., Ziegele, F. (2012): Multidimensional Ranking: The Design and Development of U-Multirank, Springer. Dordrecht

- World Bank Databank (2009): WB Databank /online/, Retrieved on $30^{\text {th }}$ December 2009 from http://databank.worldbank.org/

- Zirulnick, A. (2010): New world university ranking puts Harvard back on top, Christian Science Monitor, Boston, MA 
Prof. dr Milica Vujičić

Državni univerzitet u Novom Pazaru

- Departman za ekonomske nauke

Doc. dr Lela Ristić

Ekonomski fakultet, Univerzitet u Kragujevcu

\section{SISTEM VISOKOG OBRAZOVANJA U REPUBLICI SRBIJI KAO PODRŠKA ODRŽIVOM RAZVOJU: IZAZOVI EVROPSKIH INTEGRACIJA}

\section{S a ž e t a k}

Tema rada je sistem visokog obrazovanja u Republici Srbiji, u kontekstu promena obrazovnih paradigmi i održivog razvoja nacionalne ekonomije zasnovane na znanju i inovacijama. Predmet istraživanja je visoko obrazovanje, kao esencijalna komponenta održivog razvoja i opredeljenja da postane sastavni deo evropskog visokoobrazovnog prostora. Cilj rada je da se sagleda trenutno stanje u ovoj oblasti i dometi nove Strategije visokog obrazovanja do 2020. godine, u uslovima ekspanzije visokog obrazovanja na globalnom nivou. U procesu evropskih integracija, nastala je izražena suprotstavljenost kratkoročnih ekonomskih interesa i razvojne misije obrazovanja, pa je glavni izazov sa kojim se suočava obrazovni sistem u Srbiji, kako izgraditi savremeni model obrazovanja koji će doprinositi razvoju pojedinca i održivom razvoju društva u celini. Takođe, velike neujednačenosti nivoa razvijenosti regiona u Srbiji, visoka nezaposlenost, depopulacioni trendovi, upućuju na zaključak da se razvoj nacionalne ekonomije mora zasnivati na podizanju stvaralačkih i proizvodnih kvaliteta ljudskih resursa tokom čitavog njihovog života. U prošlosti je bilo dvadesetak reformi obrazovnog sistema u Srbiji, ali uvek parcijalno, bez dobrog uvida o implikacijama tih reformi. Zato, pored ključne hipoteze od koje se u radu polazi, da visoko obrazovanje ima krucijalnu ulogu u suočavanju sa mnogim socio-ekonomskim, demografskim, ekološkim i tehnološkim izazovima, značajna je i posebna hipoteza da dosadašnje reforme sistema visokog obrazovanja, pored pozitivnih promena, nisu doprinele generisanju inovativnosti, u cilju podrške održivom razvoju, transferu znanja za prevazilaženje kritičnih problema i savladavanju izazova budućnosti. S obzirom na predmet, cilj i postavljene hipoteze, u radu je primenjena kvalitativna metodologija, bazirana na proučavanju i deskriptivnoj analizi definisanog problema, uz primenu uobičajenog naučnoistraživačkog instrumentarijuma. Analiza relevantne literature, publikacija međunarodnih organizacija, zvaničnih statističkih izvora i empirijskih istraživanja, ukazala je na potrebu unapređenja kvaliteta obrazovnog procesa i korišćenja ishoda učenja, odnosno, neophodnost suštinskih promena visokoobrazovnog sistema, u cilju izgradnje novog modela visokog obrazovanja u Srbiji, u procesu evropskih integracija. Rad se, nakon uvoda, sastoji iz sledećih delova: 
Ekspanzija znanja i internacionalizacija visokog obrazovanja; Razvoj sistema visokog obrazovanja u Republici Srbiji; Konkurentnost u visokom obrazovanju Srbije; Internacionalizacija i saradnja u oblasti visokog obrazovanja; Neophodnost implementacije novog modela visokog obrazovanja, i Zaključna razmatranja.

Ključne reči: visoko obrazovanje, održivi razvoj, interaktivno učenje, metodologije vrednovanja, model nastave/učenja, Republika Srbija, Evropska unija 